\section{p-ISSN 2476-9886 \\ e-ISSN 2477-0302 \\ J.Edu}

Volume 4 Nomor 1, April 2018, HIm 31-39

\section{Jurnal EDUCATIO}

Jurnal Pendidikan Indonesia

DOI: https://doi.org/10.29210/120182135

Akses Online :

http://jurnal.iicet.org

Dipublikasikan oleh :

Indonesian Institute for Counseling, Education and Therapy (IICET)

Info Artikel:

Diterima: 02/03/2018 Direvisi: 21/03/2018 Dipublikasikan: 15/04/2018

\title{
PENINGKATAN AKTIVITAS DAN HASIL BELAJAR TENTANG PECAHAN DENGAN MENGGUNAKAN MEDIA MANIPULATIF DARI KERTAS SISWA SEKOLAH DASAR
}

\author{
Erni Yanti ${ }^{1}$ \\ ${ }^{1}$ SD Negeri 12 Api - Api
}

\begin{abstract}
The study was conducted on third-grade students of SD Negeri 12 Api - Api Kecamatan Bayang in the lesson of 2016/2017 using classroom action research (PTK). The study was conducted in two cycles. The instruments used to collect data are test sheets and observation sheets. The results showed an increase in cycles, I and II, so it can be concluded that paper manipulative media can increase student activity and learning outcomes about fractions.
\end{abstract}

Keyword: manipulative media from paper, classroom action research

(c) (1) This is an open access article distributed under the Creative Commons Attribution License, which permits unrestricted use, distribution, and reproduction in any medium, provided the original work is properly cited. (C2017 by author and Indonesian Counselor Association (IKI).

\section{PENDAHULUAN}

Keberhasilan suatu pendidikan sangat ditentukan oleh kemampuan guru dalam menyampaikan materi pelajaran kepada peserta didik untuk menerima materi pelajaran yang di maksud. Matematika adalah salah satu mata pelajaran yang dipelajari mulai dari pendidikan dasar, dan seringkali dianggap sebagai mata pelajaran yang paling sulit dibandingkan dengan mata pelajaran yang lainnya. Sebagai seorang guru kita tidak bisa berdiam diri manakala melihat kasus-kasus seperti ini, kita harus bertanya dan mencari jalan keluarnya untuk dapat memecahkan masalah tersebut. Kalau kita menginginkan pembelajaran Matematika dapat berhasil dengan baik maka kita harus menguasai materi yang akan disajikan dan menggunakan alat peraga yang tepat sesuai dengan materi yang kita ajarkan serta kita harus jeli dalam memelih metode dan media pembelajaran.

Selama ini pembelajaran matematika di kelas III Sekolah Dasar Negeri 12 Api - Api Kec. Bayang didominasi oleh guru. Pelajaran diberikan kepada siswa dengan metode ceramah dan tanya jawab. Tetapi banyak siswa hanya mendengar dan menonton kemudian mencatatnya tanpa mengerti apa yang dicatatnya. Sewaktu diberikan latihan dan tugas oleh guru, hanya beberapa orang yang sungguh-sungguh mengerjakan. Siswa yang lain banyak mencari kegiatan lain, kemudian menyalin tugas teman yang telah selesai. Hal ini membuat siswa 
tidak merasa tertarik dalam mengerjakan tugas atau latihan tersebut. Pembelajaran seperti di itu membuat siswa pasif, sehingga aktivitas belajar yang terjadi rendah. Rendahnya aktivitas dapat dilihat dari mengerjakan tugas.

Hal lain yang ditemukan dalam kegiatan pembelajaran di sekolah adalah rendah hasil belajar matematika siswa kelas III Sekolah Dasar Negeri 12 Api - Api Kec. Bayang. Hal ini terlihat dari banyaknya siswa yang belum mencapai Kriteria Ketuntasan Minimal (KKM) baik ditinjau dari segi pemahaman konsep, penalaran dan komunikasi maupun pemecahan masalah. Jika pemahaman konsep siswa belum tuntas maka siswa tidak akan bisa menalar dan berkomunikasi begitu juga dengan pemecahan masalah. Rata-rata ketuntasan hasil belajar siswa kelas III Sekolah Dasar Negeri 12 Api - Api Kec. Bayang adalah 50. Sedangkan KKM untuk matematika di Sekolah Dasar Negeri 12 Api - Api Kec. Bayang adalah 70. Untuk mencapai KKM tersebut siswa harus mengikuti beberapa kali remedial.

Berdasarkan permasalahan di atas, maka perlu adanya suatu pemecahan masalah. Guru sebagai salah satu komponen yang menentukan keberhasilan pembelajaran di sekolah terus dituntut untuk menciptakan suasana pembelajaran yang menyenangkan sehingga dapat meningkatkan aktivitas dan hasil belajar siswa. Salah satu alternatif yang diyakini dapat mengatasi masalah di atas adalah dengan media bahan manipulatif. Dalam cara penyajian materi bersifat menyenangkan dan dalam suasana yang gembira serta mengasyikkan menggunakan media bahan manipulatif sambil belajar membuat siswa merasa lebih rileks dalam menghadapi pembelajaran, dengan sendirinya materi pelajaran akan lebih mudah dimengerti (Fredrik, 2005:10) dan siswa dapat terhindar ari stress akademik (Zola, N., Fadli, R. P., \& Ifdil, I., 2017; Taufik, T., \& Ifdil, I., 2013; Barseli, M., \& Ifdil, I., 2017). Namun tidak semua media bahan manipulatif mudah digunakan dan diotak-atik. Untuk siswa kelas III pembelajaran pecahan yang dilakukan adalah yang lebih mengarah pada penguasaan tiga domain yakni kognitif, afektif, dan psikomotor seperti media bahan manipulatif (Hurlock, 1996:218). Salah satu pembelajaran pecahan yang bisa digunakan adalah media bahan manipulatif. Media bahan manipulatif dirancang untuk menciptakan suasana lingkungan belajar yang rileks dan siswa dapat memahami konsep matematika sambil mengarsir (Melva, 2001:1). Penggunaan media bahan manipulatif juga bisa dilakukan berkelompok. Karena dengan berkelompok siswa bisa berdiskusi dalam mengarsir gambar serta dapat membantu teman yang dalam kesulitan. Bagi siswa yang malu untuk bertanya mereka bisa bertanya kepada temannya. Jadi akan tercipta kedekatan siswa dengan guru dan siswa dengan siswa (Melva, 2003:4).

Berkaitan dengan perkembangan mental anak berkembang secara bertahap dan sederhana ke yang rumit, dan mulai dari yang nyata ke abstrak. Urutan tersebut dapat membantu siswa untuk mengikuti pembelajaran lebih mudah. Bahan atau media yang dirancang terkait usia atau umur anak, sehingga tercapailah tujuan pembelajaran matematika. Menurut Bruner (dalam Gatot Muhsetyo, 2007:12), tiga tingkatan yang perlu diperhatikan dalam mengakomodasikan keadaan siswa, yaitu:“ (a) enactive (manipulasi objek langsung), (b) iconic (manipulasi objek tidak langsung; dan (c) symbolic (manipulasi simbol). Penggunaan berbagai objek dalam berbagai bentuk dilakukan setelah melalui pengamatan yang teliti bahwa memang benar objek itu yang diperlukan. Sebagai contoh bagi anak SD kelas I, tentu mereka dalam situasi enactive, artinya matematika lebih banyak diajarkan dengan manipulasi objek langsung dengan memanfaatkan kerikil, kelereng, manik-manik, potongan kertas, bola, kotak, karet, dan sebagainya, dan dihindari penggunaan langsung simbol-simbol huruf dan lambang-lambang operasi yang berlebihan".

Menurut Gagne (dalam Azhar, 2003:4): "bahwa media pembelajaran meliputi alat yang secara fisik digunakan untuk menyampaikan isi materi pengajaran yang terdiri dari buku, kertas, bola, kotak, gambar, foto, kaset, televisi dan komputer". Di samping itu menurut Hamidjojo (dalam Ahzar 2003:4) menjelaskan bahwa:"media adalah sebagai sebuah bentuk perantara yang digunakan oleh manusia untuk menyampaikan atau menyebarkan ide, gagasan, atau pendapat sehingga ide, gagasan yang dikemukakan itu sampai kepada penerima dengan baik.

Berdasarkan definisi diatas dapat disimpulkan bahwa media adalah sebagai alat perantara yang digunakan guru untuk menyampaikan materi pelajaran untuk sehingga dengan menggunakan media akan sangat membantu keefektifan proses pembelajaran dan penyampaian isi pesan materi pelajaran oleh guru saat itu". 
Seiring dengan hal tersebut, peneliti merasa terpanggil untuk mencoba memberikan solusi yang menurut peneliti mampu memperbaiki keadaan pembelajaran seperti yang telah diuraikan di atas. Peneliti yakin bila dengan menerapkan media bahan manipulatif dari kertas dalam pembelajaran matematika dengan pecahan untuk kelas III, akan dapat meningkatkan aktivitas dan hasil belajar yang diperoleh siswa serta tercapainya beberapa tujuan matematika yang tercantum dalam Standar Kompetensi dan Kompetensi Dasar Tingkat SD/MI (2007:10).

Berdasarkan hal tersebut maka dengan menerapkan media bahan manipulatif diharapkan dapat meningkatkan aktivitas siswa seperti aktivitas mengerjakan tugas, bertanya, menjawab pertanyaan, mengeluarkan pendapat, berdiskusi, membantu teman yang mengalami kesulitan, dan mencatat hasil diskusi dan hasil belajar pemahaman konsep dan penalaran dan komunikasi siswa. Untuk itu penulis akan mengadakan penelitian tindakan kelas yang berjudul "Upaya Meningkatkan Aktivitas dan Hasil Belajar Siswa Tentang Pecahan Dengan Menggunakan Media Manipulatif Dari Kertas di Kelas III SD Negeri 12 Api - Api Kecamatan Bayang Kab. Pesisir Selatan"

\section{METODOLOGI}

Penelitian ini dilaksanakan di SD Negeri 12 Api - Api Kecamatan Bayang Kabupaten Pesisir Selatan pada mata pelajaran matematika di kelas III. Penelitian dilakukan dalam dua siklus. Siklus I terdiri dari lima kali pertemuan dan siklus II terdiri dari tiga kali pertemuan. Setiap siklus terdiri atas empat komponen sesuai dengan model Kurt Lewin dalam Aleks Maryunis (2003:117) yaitu:(1) perencanaan (planning); (2) tindakan (acting); (3) pengamatan (observing); (4) refleksi (reflecting).

Instumen yang digunakan untuk mengumpulkan data adalah lembaran tes dan lembaran observasi. Teknik pengumpulan data dengan mengumpulkan data dan digunakan sebagai dasar menilai keberhasilan atau ketidakberhasilan tindakan perbaikan pembeljaran yang dicobakan, meliputi 1) data aktivitas 2) data hasil belajar. Analisis data menggunakan analisis kuantitatif.

\section{HASIL DAN PEMBAHASAN}

\section{Siklus I}

\section{1) Aktivitas Siswa}

Aktivitas belajar siswa diperoleh dari hasil observasi yang dilakukan oleh supervisor mulai dari guru memulai pembelajaran dari pendahuluan, guru menjelaskan pelajaran, siswa duduk berkelompok, siswa berdiskusi dengan menggunakan media bahan manipulatif dalam kelompok, siswa presentasi sampai pada penarikan kesimpulan. Aktivitas belajar siswa yang diamati adalah:(1) aktivitas mengajukan pertanyaan kepada guru maupun teman; (2) aktivitas memberi jawaban/tanggapan tentang pertanyaan guru maupun teman; (3) aktivitas mengeluarkan ide/pendapat dalam kerja kelompok (terlibat dalam diskusi kelompok); (4) aktivitas mengerjakan soal pada materi pecahan maupun yang diberikan guru; (5) aktivitas memberikan bantuan terhadap teman yang mengalami kesulitan dalam belajar maupun dalam kelompok; (6) aktivitas mencatat atau membuat catatan sendiri tentang penjelasan guru maupun hasil diskusi dan (7) kegiatan yang tidak relevan. 


\section{Diagram 1. Aktivitas Siswa Siklus I}

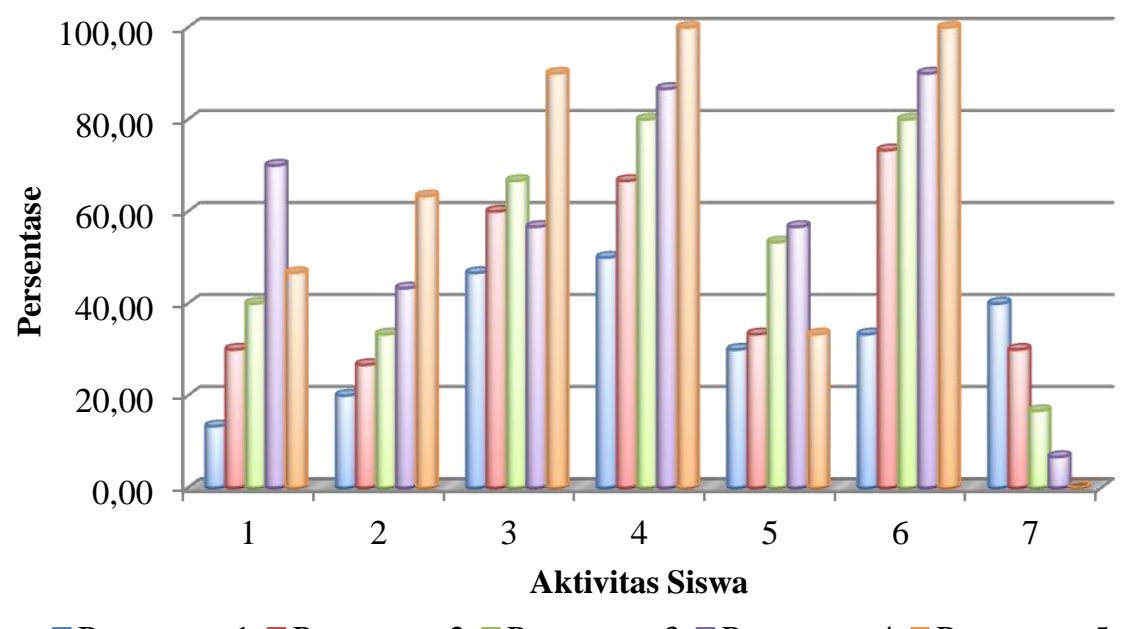

\section{2) Refleksi Aktivitas Siswa}

a) Untuk aktivitas mengajukan pertanyaan kepada guru maupun teman dari pertemuan pertama sampai pertemuan keempat terjadi peningkatan aktivitas sedikit, sedangkan pada pertemuan kelima aktivitas kembali menurun. Hal ini terjadi karena pada pertemuan kelima materinya tidak terlalu sulit sehingga siswa tidak terlalu banyak bertanya-tanya kepada guru maupun kepada sesama siswa. Juga sewaktu presentasi siswa juga tidak antusias untuk menanggapi. Guru kurang menyebar pertanyaan. Urutan pada soal pada pertemuan kelima mudah untuk diterka dan terurut langkah-langkah jawaban dan soal pada materi pecahan.

b) Aktivitas memberikan menjawab pertanyaan dari guru maupun teman setiap pertemuan terjadi peningkatan aktivitas namun belum mencapai kategori baik. Hal ini terjadi karena siswa masih malu untuk menjawab pertanyaan dari guru. Siswa menjawab kalau sudah ditunjuk oleh guru. Sewaktu presentasi, siswa yang tampil saja yang menjawab, anggota kelompok yang lain tidak ikut menjawab walaupun sudah diarahkan oleh guru.

c) Aktivitas mengeluarkan pendapat dalam kerja kelompok (terlibat dalam diskusi kelompok) dari pertemuan pertama sampai pertemuan kelima terjadi peningkatan aktivitas, bahkan untuk pertemuan kelima sudah mencapai kategori baik. Hal ini terjadi karena siswa sangat antusias untuk ikut menjawab media bahan manipulatif apalagi yang akan diturunkan. Siswa begitu senang dan semangat untuk menjadi pemenang.

d) Aktivitas mengerjakan soal yang terdapat pada media bahan manipulatif maupun yang diberikan guru terjadi peningkatan yang baik, hanya pada pertemuan pertama saja yang belum mencapai kategori baik. Hal ini terjadi karena siswa ingin mengulangi permainan media bahan manipulatif ini di luar jam sekolah. Juga siswa merasa senang dalam belajar, tidak merasa terpaksa untuk belajar, jadi mengerjakan soal tidak terpaksa lagi.

e) Aktivitas memberikan bantuan terhadap teman yang mengalami kesulitan dalam belajar maupun mengerjakan soal pada media bahan manipulatif dari pertemuan pertama sampai pertemuan keempat, terjadi sedikit peningkatan aktivitas. Hal ini terjadi karena siswa ingin menjadi pemenang pada pertemuan ini sehingga siswa tidak sempat menjelaskan sama temannya. Juga di dalam kelompok ada siswa pintar yang tidak bisa menjelaskan pada temannya, sehingga siswa malu untuk bertanya kepada temannya. Akhirnya siswa hanya menyalin saja hasil kerja temannya walaupun tidak mengerti. Kalau pada pertemuan kelima terjadi penurunan karena materi tidak terlalu sulit dan soal pada media bahan manipulatif mudah untuk dibaca. Akibatnya siswa bekerja sendiri dan tidak perlu untuk bertanya kepada temannya.

f) Aktivitas mencatat atau membuat catatan sendiri tentang penjelasan guru dan hasil diskusi hanya pada pertemuan pertama saja yang belum mencapai kategori baik. Selebihnya sudah mencapai kategori baik. Hal ini terjadi karena siswa punya keinginan untuk mengulangi di luar jam pelajaran. Karena siswa cepat selesai 
menyusun media bahan manipulatif, siswa punya kesempatan untuk mencatat sambil menunggu kelompok lain selesai.

g) Selama pembelajaran berlangsung kegiatan siswa yang tidak relevan sudah berkurang bahkan pada pertemuan kelima semua siswa sudah sibuk untuk mencatat dan serius mengikuti pembelajaran dengan perasaan senang. Suasananya pembelajaran tidak membosankan lagi.

Dari refleksi pada siklus I terjadi kelemahan pada aktivitas mengajukan pertanyaan kepada guru maupun teman, aktivitas pertanyaan guru maupun teman dan aktivitas memberi bantuan terhadap teman yang mengalami kesulitan dalam belajar maupun mengerjakan soal pada materi pecahan yang telah dijelaskan di atas. Untuk mengatasi kelemahan tersebut maka dilakukan revisi tindakan yang telah dilakukan pada siklus I. Revisi tindakan yang dilakukan untuk siklus II adalah:(1) perubahan anggota kelompok; (2) soal yang dibuat pada materi pecahan tidak langsung bisa diterka dan soal pada materi pecahan lebih banyak hitungan; (3) kelompok yang presentasi, semua anggota tampil kedepan untuk presentasi; (4) aturan penilaian adalah nilai kelompok tidak lagi mengutamakan kelompok yang pertama siap tetapi nilai kelompok adalah jika semua anggota kelompok bisa menjawab pertanyaan dari guru dan kekompakan kelompok; (5) guru menguji semua anggota secara lisan, kelompok 'yang telah selesai mengerjakan soal materi pecahan; (6) guru menyebar pertanyaan dan jawaban dari siswa.

\section{3) Hasil Belajar}

Dari siklus I hasil belajar yang diperoleh siswa yaitu Pemahaman Konsep, Penalaran dan Komunikasi (PKom) belum mencapai $75 \%$ tuntas secara klasikal. Untuk PK hanya 22 orang yang tuntas $(73,33 \%$ tuntas secara klasikal), sedangkan untuk PKom hanya 11 orang yang tuntas (36,67\% tuntas secara klasikal).

\section{Diagram 2 Hasil Belajar Siklus I}
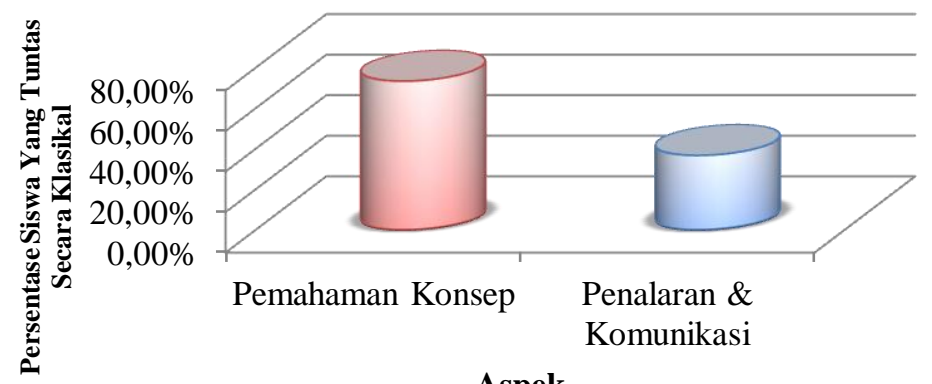

Aspek

\section{4) Refleksi Hasil Belajar Siswa}

Dari diagram ketuntasan pemahaman konsep lebih baik dari pada penalaran komunikasi. Hal ini terjadi karena soal pada media bahan manipulatif lebih banyak pada pemahaman konsep dan ada yang bisa diterka tanpa harus dicari, sedangkan pada penalaran dan komunikasi soal betul-betul harus dicari. Siswa kurang terlatih untuk menyelesaikan soal dengan langkah-langkah yang sebenarnya. Sewaktu diskusi menyusun media bahan manipulatif siswa terburu-buru waktu untuk jadi pemenang sehingga siswa banyak yang mencatat hasil temannya walaupun siswa tidak mengerti apa yang dicatatnya. Jika siswa yang tidak mengerti tidak mau bertanya kepada teman untuk soal yang tidak dimengerti, begitu pula sebaliknya ada siswa yang tidak mau menjelaskan karena terburu waktu untuk jadi pemenang. Hal ini juga karena aktivitas siswa ada yang belum mencapai kategori baik. Untuk mengatasi hal ini maka dilakukan perubahan perlakuan yang telah disebutkan di atas pada siklus II.

\section{Siklus II}

Hasil refleksi pada siklus I yang belum mencapai kriteria yang diinginkan dalam penelitian ini maka dilanjutkan pada siklus II. Pada siklus II masih menggunakan metode permainan media bahan manipulatif dengan melakukan beberapa perubahan yang telah disebutkan pada refleksi siklus I. Siklus II dilaksanakan tiga kali 
pertemuan yaitu tanggal 09, 16, 23 Maret 2017. Tes hasil belajar siklus II dilaksanakan pada tanggal 30 Maret 2017. Hasil dari pengamatan aktivitas disajikan berikut ini dan hasil belajar disajikan seperti berikut.

\section{1) Aktivitas Siswa}

Aktivitas siswa yang diamati dimulai dari pendahuluan, guru menjelaskan, siswa duduk berkelompok, siswa diskusi kelompok, siswa presentasi, dan terakhir menarik kesimpulan bersama siswa.

\section{Diagram 3 Aktivitas Siswa Siklus II}

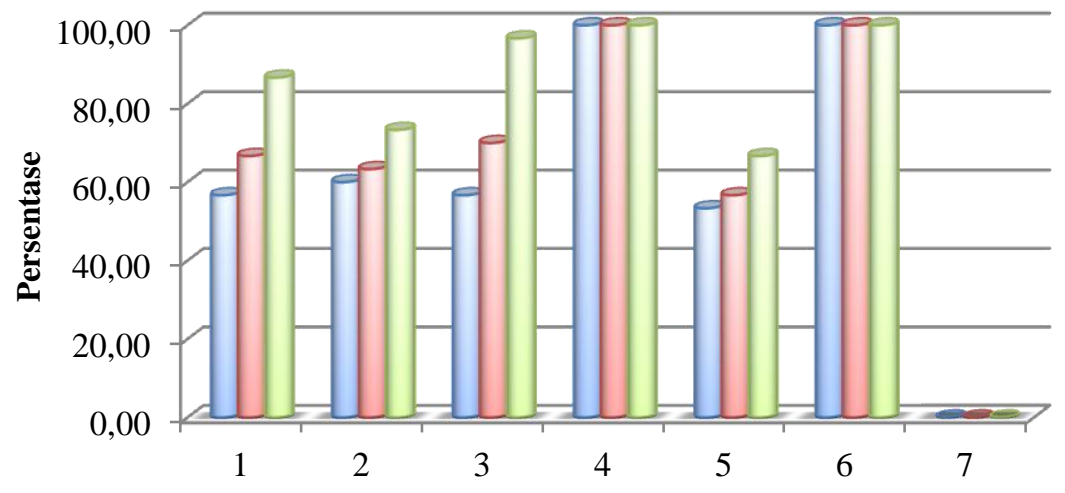

Aktivitas Siswa

$\square$ Pertemuan $1 \quad \square$ Pertemuan $2 \quad \square$ Pertemuan 3

\section{2) Refleksi Aktivitas Siswa}

Dengan melakukan perubahan pada siklus II, semua aktivitas siswa sudah mencapai kategori baik, kecuali untuk aktivitas siswa memberikan bantuan terhadap teman yang mengalami kesulitan dalam belajar maupun mengerjakan soal pada media bahan manipulatif belum mencapai kategori baik terapi sudah mencapai kategori cukup. Hal ini karena siswa sudah serius memperhatikan sehingga mereka cepat mengerti karena siswa terlibat dalam diskusi dan mengerjakan soal. Sehingga siswa tidak terlalu banyak bertanya kepada teman. Suasana pembelajaran yang menyenangkan membuat siswa yang tidak mengerti mau bertanya tanpa rasa takut atau malumalu bertanya kepada gurunya. Kegiatan yang tidak relevan tidak ada lagi karena siswa sibuk mencari soal yang ada pada media bahan manipulatif. Siswa harus mengerti soal yang ada pada media bahan manipulatif jika tidak nilai kelompok jadi rendah. jika siswa tidak mengerti ada siswa lain yang menjelaskan. Karena aktivitas siswa sudah mencapai kategori baik maka siklus berhenti pada siklus II.

\section{3) Hasil Belajar}

Dari siklus II hasil belajar yang diperoleh siswa yaitu Pemahaman Konsep (PK) dan Penalaran dan Komunikasi (PKom) sudah 75\% tuntas secara klasikal yaitu untuk PK siswa yang tuntas 24 siswa (80\% tuntas secara klasikal) dan untuk PKom siswa yang tuntas 27 siswa (90\% tuntas secara klasikal). 


\section{Diagram 4 Hasil Belajar Siklus II}

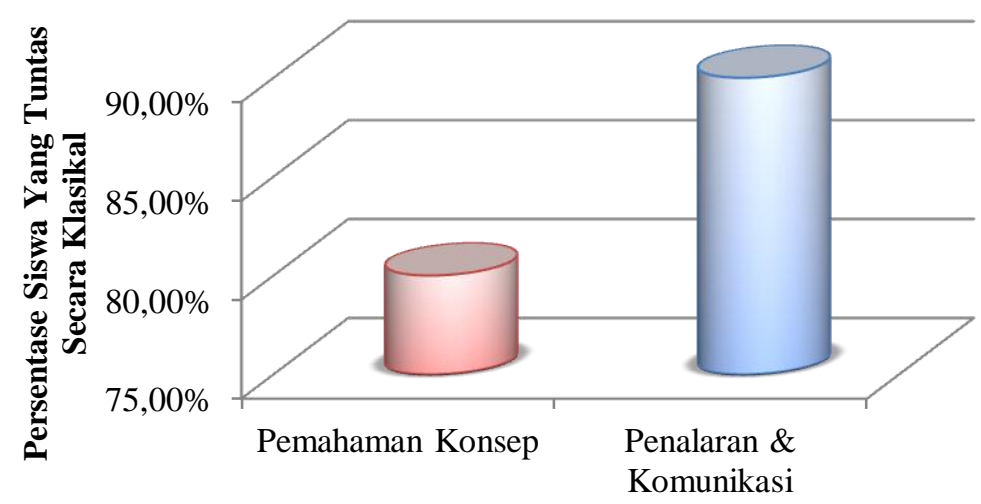

Aspek

\section{4) Refleksi Hasil belajar}

Dari diagram terlihat bahwa pemahaman konsep lebih rendah dari penalaran dan komunikasi. Hal ini terjadi karena pada pemahaman konsep siswa ceroboh karena menganggap soal itu mudah. Sedangkan pada penalaran dan komunikasi jauh meningkat dibandingkan dari siklus I karena siswa betul-betul ikut mengerjakan soal pada materi pecahan dan sudah mengerti apa yang dicatat. Karena semua aktivitas siswa sudah mencapai kriteria baik dan hasil belajar siswa juga sudah lebih 75\% tuntas secara klasikal maka siklus berhenti sampai disini.

\section{PEMBAHASAN}

\section{1) Aktivitas Siswa}

Pembahasan hasil penelitian terdiri atas tiga tahap, yaitu (1) kegiatan awal, (2) kegiatan inti, (3) kegiatan akhir. Sebelum diuraikan tahap tersebut akan diuraikan terlebih dahulu perencanaan tindakan. Berdasarkan hasil penelitian penggunaan media gambar seri meningkatkan keterampilan berbicara siswa bahwa rencana pembelajaran yang dibuat secara kolaboratif dengan guru kelas III SDN. 14 Siguntur Muda Kecamatan Koto XI Tarusan Kabupaten Pesisir Selatan. Dalam perencanaan terdapat unsur-unsur, Standar Kompetensi (SK), Kompetensi Dasar (KD), indikator, langkah-langkah pembelajaran, media, dan penilaian.

Tabel 1. Perbadingan Aktivitas siswa Siklus I dan Siklus II

\begin{tabular}{|c|c|c|c|c|}
\hline \multirow[t]{2}{*}{ No. } & \multirow[t]{2}{*}{ Aktivitas Siswa } & \multicolumn{2}{|c|}{ Rata-rata (\%) } & \multirow{2}{*}{$\begin{array}{c}\text { Pening- } \\
\text { katan }\end{array}$} \\
\hline & & $\begin{array}{c}\text { Siklus } \\
\text { I }\end{array}$ & $\begin{array}{c}\text { Siklus } \\
\text { II }\end{array}$ & \\
\hline 1 & Mengajukan pertanyaan kepada guru atau teman & 40.00 & 70.00 & 30.00 \\
\hline 2 & Menjawab pertanyaan guru maupun teman & 37.33 & 65.56 & 28.23 \\
\hline 3 & $\begin{array}{l}\text { Mengeluarkan ide/ pendapat dalam kerja kelompok } \\
\text { (terlihat dalam diskusi kelompok) }\end{array}$ & 64.00 & 74.44 & 10.44 \\
\hline 4 & $\begin{array}{l}\text { Mengerjakan soal yang terdapat pada media bahan } \\
\text { manipulatif maupun yang diberikan guru }\end{array}$ & 76.67 & 100.00 & 23.33 \\
\hline 5 & $\begin{array}{l}\text { Memberikan bantuan terhadap teman yang } \\
\text { mengalami kesulitan dalam belajar maupun } \\
\text { mengerjakan soal pada media bahan manipulatif }\end{array}$ & 41.33 & $\mathbf{5 8 . 8 9}$ & 17.56 \\
\hline
\end{tabular}




\begin{tabular}{lllll}
6 & $\begin{array}{l}\text { Mencatat atau membuat catatan sendiri tentang } \\
\text { penjelasan guru dan hasil diskusi }\end{array}$ & $\mathbf{7 5 . 3 3}$ & $\mathbf{1 0 0 . 0 0}$ & $\mathbf{2 4 . 6 7}$ \\
7 & Kegiatan yang tidak relevan & 18.67 & 0.00 & -18.67 \\
\hline
\end{tabular}

2) Hasil Belajar belajar.

Data hasil belajar siswa yang dijaring dari tes hasil belajar diakhir setiap siklus terjadi peningkatan hasil

Tabel 2. Perbadingan Aktivitas siswa Siklus I dan Siklus II

\begin{tabular}{ccc}
\hline Siklus & \multicolumn{2}{c}{ Persentase dan Jumlah Siswa yang Telah Mencapai $\geq 65$} \\
\cline { 2 - 3 } & Pemahaman Konsep & Penalaran dan Komunikasi \\
I & $(73,33)$ & $(36,67)$ \\
II & $(\mathbf{8 0})$ & $(90)$ \\
\hline
\end{tabular}

Dari hasil diatas kita bisa mengetahui, Pembelajaran dengan menggunakan media bahan manipulatif dari kertas dapat menciptakan suasana yang menyenangkan dan melibatkan banyak aktivitas siswa dalam pembelajaran sehingga pelajaran cepat untuk dimengerti dan terciptanya komunikasi yang baik antara siswa dengan siswa dan siswa dengan guru seperti dijelaskan Fredrik (2005:9) bahwa permainan dapat menghidupkan suasana pembelajaran yang menyenangkan dan dalam suasana yang gembira.

Disamping itu pembelajaran dengan media bahan manipulatif dari kertas menyenangkan sehingga siswa betul-betul mengerjakan soal dengan media bahan manipulatif dari kertas dan siswa terlihat dalam diskusi dalam menggunakan media bahan manipulatif dari kertas. Siswa mengerjakan semua soal yang diberikan guru maupun soal dengan media bahan manipulatif dari kertas dengan sungguh-sungguh. Seperti yang dijelaskan oleh Percival \& Henry (1988:89):penggunaan permainan dalam pembelajaran dimana ada unsur persaingan didalamnya, maka hal ini dapat menimbulkan motivasi yang kuat bagi siswa untuk mengerjakan tugas-tugas secara penuh.

\section{SIMPULAN DAN SARAN}

Setelah dilakukan penelitian tindakan kelas ini berdasarkan hasil persentase dan hasil refleksi yang telah dilakukan selama penelitian, maka disimpulkan:

1. Pembelajaran dengan menggunakan media bahan manipulatif dari kertas dapat meningkatkan aktivitas belajar matematika siswa kelas III SD Negeri 12 Api - Api Kecamatan Bayang. seperti aktivitas bertanya, menanggapi/menjawab pertanyaan, diskusi, memecahkan soal, membantu teman yang kesulitan dan mencatat.

2. Pembelajaran dengan menggunakan media bahan manipulatif dari kertas dapat meningkatkan hasil belajar matematika siswa kelas III SD Negeri 12 Api - Api Kecamatan Bayang.pada pemahaman konsep dan penalaran dan komunikasi, KKM 70 dan ketuntasan klasikal $\square \mathbf{8 0 \%}$.

Kelemahan yang muncul dalam penelitian ini adalah bahwa sewaktu-waktu presentasi waktunya sangat terbatas, sehingga siswa yang mau menanggapi sangat terbatas, padahal siswa sangat antusias untuk menanggapi, juga situasi kelas menjadi ribut. Soal dengan media bahan manipulatif dari kertas juga terbatas, jika soalnya sulit maka waktu untuk menggunakan media bahan manipulatif dari kertas tidak cukup. Untuk itu bagi peneliti lain diharapkan agar:

1. Waktu presentasi ditambah sehingga siswa yang menanggapi bisa lebih banyak.

2. Siapkan media bahan manipulatif dari kertas sesuai dengan kemampuan siswa kita. 
3. Karena ini baru penelitian awal maka bagi peneliti lain dapat untuk melanjutkan sejauhmana penggunaan media bahan manipulatif dari kertas dapat membuat pembelajaran yang menyenangkan dan bagaimana hasil belajar aspek pemecahan masalah.

\section{DAFTAR RUJUKAN}

Abdullah bin Abbas. (2008). Matematika Realisti:Apa dan Bagaimana?.

Arief, Sadiman. (1986). Media Pendidikan. Jakarta:Pustekom Dikbud dan PT. Raja Grafindo.

Aleks Maryunis. (2003). Action Research dalam Bidang Pendidikan. Solar Jurnal Pendidikan. Vol. 4 No. 1:Hal. 111-137.

Arsyad, Azhar. (1997). Media Pengajaran. Jakarta. PT Raja Grafindo Persada

B. Hamzah. (2009). Konsep Pembelajaran Berbasis Kecerdasan. Jakarta:Bumi Aksara.

Barseli, M., \& Ifdil, I. (2017). Konsep Stres Akademik Siswa. Jurnal Konseling dan Pendidikan, 5(3), $143-148$.

Depdiknas. (2003). Undang-Undang Pendidikan Nasional. Jakarta:Depdikbud.

Gatot Muhsetyo dkk (2007). Pembelajaran Matematika SD. Departemen Pendidikan Nasional Jakarta:Universitas Terbuka

Mardiah Harun, dkk. (2010). Pemahaman dan Pembealjaran di Sekolah Dasar. Padang:Cukabina Press.

M. Ngalim Purwanto. (1991). Prinsip-Prinsip dan Teknik Evaluasi Pengajaran. Jakarta :Rosdakarya.

M. Ngalim Purwanto. (1996). Psikologi Pendidikan. Bandung :Remaja Rasdakarya.

Nana Sudjana. (1991). Teknologi Pengajaran. Bandung, PT. Sinar Baru

Nana Sudjana. (1991). Media Pengajaran. Bandung:PT. Sinar Baru

Nana Sudjana. (1989). Metodologi Statistik:Bandung:Tarsito Bandung. Edisi Keenam.

Omar Hamalik. (1993). Metodik Belajar dan Kesulitan Belajar. Bandung :Ganesha

Omar Hamalik. (1994). Media Pendidikan. Cetakan ke VII. Bandung:Citra Aditya Bakti.

Permendiknas No.22. (2006). Standar Isi:Jakarta:Departemen Pendidikan.

Permendiknas. (2007). Kurikulum 2004 (Standar Kompetensi Mata Pelajaran Matematika SD/MI). Jakarta :Departemen Pendidikan Nasional

Sahertian, Piet A. (2000). Konsep Dasar dan Teknik Supervisi Pendidikan dalam Rangka Membangun Sumber Daya Manusia. Jakarta:Rineka Cipta.

Sahertian, Piet A. (2000). Konsep Dasar dan Teknik Supervisi Pendidikan dalam Rangka Membangun Sumber Daya Manusia. Jakarta:Rianika Cipta.

Tim MKDK. (1997). Belajar dan Pembelajaran . Padang:UNP

Taufik, T., \& Ifdil, I. (2013). Kondisi Stres Akademik Siswa SMA Negeri di Kota Padang. Jurnal Konseling dan Pendidikan, 1(2), 143-150.

Zola, N., Fadli, R. P., \& Ifdil, I. (2017). Chromotherapy to reducing stress. Open Science Framework. November, 20. 